Génét. Sél. Evol., 1985, 17 (2), 201-210

\title{
Allozyme variation in fourteen natural populations of Drosophila melanogaster collected from different regions of France
}

\author{
Liliane CHARLES-PALABOST, Monique LEHMANN and H. MERÇOT \\ Université de Paris VII, Laboratoire de Génétique des Populations \\ Tour 42-32, 2, place Jussieu, F 75005 Paris
}

\begin{abstract}
Summary
We analyzed allozyme variation of 6 gene loci in 14 populations of Drosophila melanogaster originating from different regions of France and captured from fruits of the localities studied (cellars excluded). With respect to these 6 loci the populations are not genetically homogeneous. Allelic frequencies at the $A d h$ locus are correlated with latitude and at the Est-6 with the kind of fruit in the habitats.

In spite of the heterogeneity of these 14 new populations, the comparison between them and 15 other French populations collected 9 or 10 years ago, in cellars, shows a remarkable similarity in the genetical composition of 4 loci among the 5 compared. Thus, the different habitats of these populations are not variable enough to enable much genetic differentiation.
\end{abstract}

Key words : Drosophila melanogaster, biochemical polymorphism, French natural populations.

\author{
Résumé \\ Polymorphisme biochimique \\ de quatorze populations naturelles de Drosophila melanogaster, \\ capturées dans différentes régions de France
}

Le polymorphisme de 6 locus enzymatiques a été analysé dans 14 populations de Drosophila melanogaster réparties du Nord au Sud de la France et capturées sur des fruits (caves à vin exclues). Un cline de fréquences avec la latitude a été mis en évidence au locus de l'Adh. Pour l'Est-6, les fréquences alléliques semblent dépendre de la nature du fruit de piégeage.

Malgré l'hétérogénéité de ces 14 nouvelles populations, la comparaison de nos résultats avec ceux concernant 15 autres populations françaises, capturées dans des caves à vin 9 ou 10 ans plus tôt, révèle une remarquable similitude dans la structure génétique de 4 des 5 locus comparés. Par conséquent, ces populations semblent vivre dans des habitats assez voisins pour ne pas entraîner de grandes différenciations génétiques.

Mots clés : Drosophila melanogaster, polymorphisme biochimique, populations naturelles françaises. 


\section{Introduction}

Generally, allozyme frequencies in natural populations of Drosophila melanogaster within the same geographical area differ slightly from one locality to another. On the contrary, when collections are made in different regions, the populations show a large-scale genetic differentiation (BERGER, 1971 ; DAVID, 1982 ; GIRARD \& Palabost, 1976 ; Girard et al., 1977 ; Johnson \& Schaffer, 1973 ; O'Brien \& MacInTYRE, 1969 ; SINGH et al., 1982). The first French populations analyzed, located in wine-cellars of the Saône and Rhône valleys (GIRARD \& PALABost, 1976; GIRARD et al., 1977) showed that the frequencies of the most common alleles at some loci ( $E s t-C$, Est-6 and $\alpha-G p d h$ ) fluctuate over wide limits ; on the contrary, at other loci (Acph, $A d h$ and $O d h$ ), allele frequencies are very similar between populations. These results could be due, either to the particular habitat of wine-cellars, or to the specific geographical localization of the populations examined.

Consequently, for a better understanding of biochemical polymorphism in French populations, it was necessary to extend the analysis to populations exclusively collected on fruit, from the North to the South of France.

\section{Material and methods}

\section{A. Collections}

Wild Drosophila melanogaster adults were collected and brought to the laboratory. Flies were frozen and then used for electrophoresis. All the collections were made during the annual demographic burst of the species (August and September).

\section{B. Populations studied}

Fourteen populations were studied; their origins are listed below : (1) Tostes near Louviers ; (2) Le Haras du Pin near Argentan; (3) Sainte-Geneviève-des-Bois near Paris ; (4) Rannée near Rennes ; (5) Nevez near Quimper ; (6) Chateaubriant ; (7) Ménétréol-sous-Sancerre near Sancerre ; (8) Bonnac-la-Côte near Limoges ; (9) Chessy-les-Mines near Villefranche-sur-Saône ; (10) Beynost near Montluel ; (11) Le Curtelod near Yenne ; (12) Allevard near Grenoble ; (13) Montauban ; (14) Tautavel near Perpignan.

Figure 1 gives the geographical localization and the fruit of the habitats.

\section{Electrophoresis}

Allozyme variation was studied by starch gel electrophoresis using Poulik's discontinuous buffer system (Poulik, 1957). Six polymorphic enzyme loci were studied, according to the techniques described in Ayala et al. (1972) : Acph (acid phosphatase ; 3-101.4), Adh (alcohol dehydrogenase; 2-50.1), Est-C (esterase-C ; 3-47.6), Est-6 (esterase $6 ; 3-36.8), \alpha-G p d h$ ( $\alpha$-glycerophosphate dehydrogenase ; 2-20.5) and Pgm (phosphoglucomutase ; 3-43.4). 


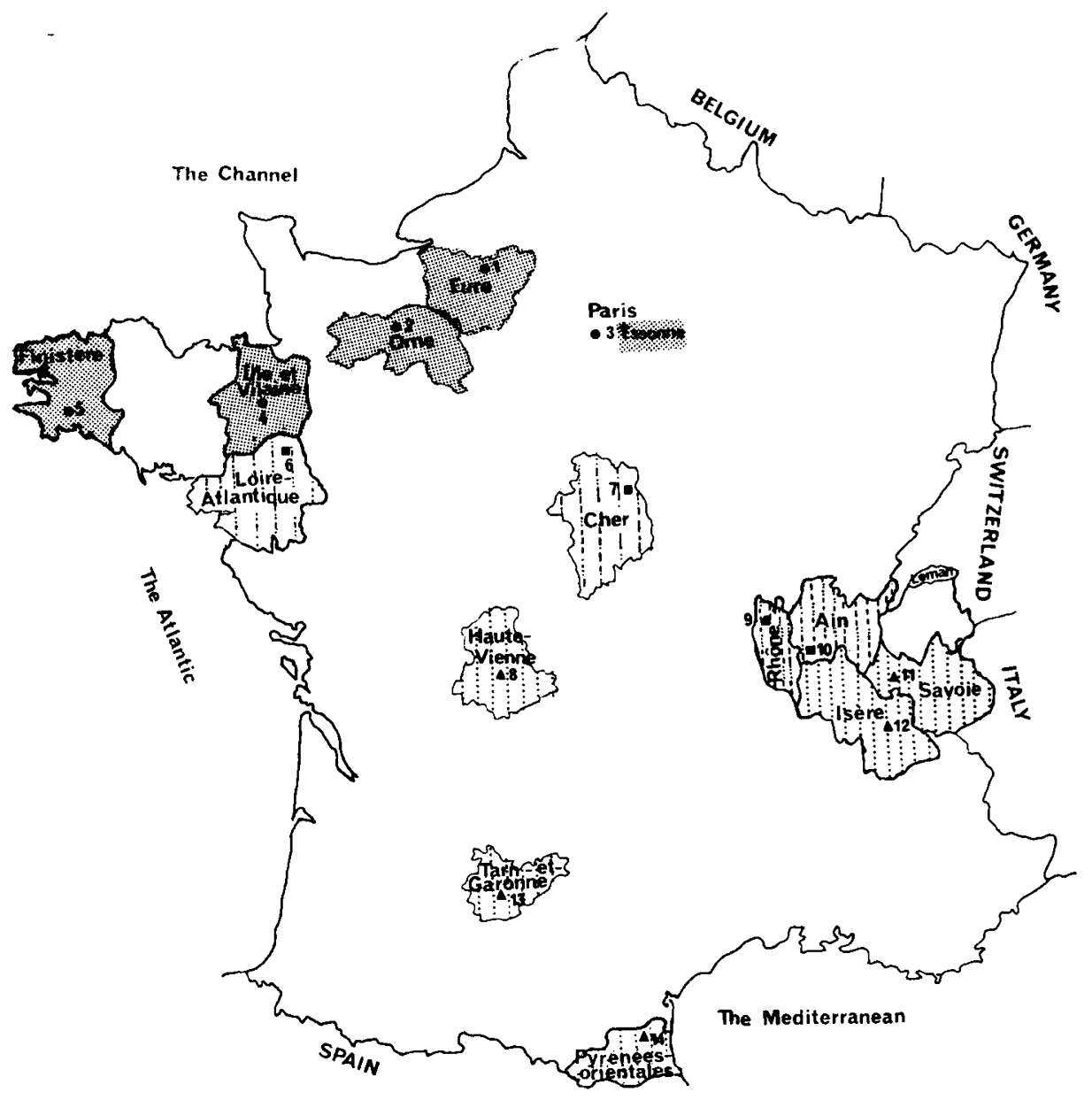

Figure 1

Geographical localization and fruit in the biotopes of the 14 French populations of Drosophila melanogaster.

Situation géographique et fruits des biotopes

de 14 populations naturelles françaises de Drosophila melanogaster.

\% apple / pommes.

Dlum / prunes.

others fruits (varied fruits such as tomatoes, melons, peaches) / autres fruits (tels que tomates, melons, pêches...). 


\section{Results}

\section{A. Allelic frequencies and comparison between the populations studied}

Table 1 gives for each population the number of genes sampled and the allelic frequencies. Homogeneity between populations was tested using a $\chi^{2}$ analysis (no $\chi^{2}$ value was available at the Acph locus, because the expected allelic numbers of the $S$ allele were too small). Table 1 shows that some geographical heterogeneity exists in the frequency distribution of the alleles at every locus, i.e., local differences exist at highly polymorphic loci (Est-6 and $\alpha-G p d h$ ) as is indeed the case at other loci.

\section{B. Comparison between our results and those previously} published by Girard \& Palabost (1976)

Since neither the present populations nor those of Girard \& Palabost (1976) were homogeneous, it was not possible to pool them in each group for a comparison

\section{TABLE 1}

Allelic frequencies at 6 polymorphic loci

in 14 French populations of Drosophila melanogaster.

Fréquences alléliques à 6 locus

dans 14 populations françaises de Drosophila melanogaster.

\begin{tabular}{|c|c|c|c|c|c|c|c|c|c|c|}
\hline \multirow[t]{2}{*}{ Populations } & \multicolumn{3}{|c|}{ Acph } & \multicolumn{3}{|c|}{$A d h$} & \multicolumn{4}{|c|}{ Est-C } \\
\hline & $\mathrm{N}$ & $F$ & $S$ & $\mathbf{N}$ & $F$ & $S$ & $\mathrm{~N}$ & $F$ & $S$ & others \\
\hline Tostes $\ldots \ldots \ldots$ & 360 & 1.000 & - & 360 & 1.000 & - & 360 & 0.994 & 0.006 & - \\
\hline Le haras du pin & 256 & 0.977 & 0.023 & 256 & 0.984 & 0.016 & 256 & 0.922 & 0.051 & 0.027 \\
\hline \multicolumn{11}{|l|}{$\begin{array}{l}\text { Sainte-Geneviève- } \\
\text { des-Bois }\end{array}$} \\
\hline Rannée .. ... & 216 & 0.958 & 0.042 & 216 & 0.986 & 0.014 & 216 & 0.995 & 0.005 & - \\
\hline Nevez . ....... & 216 & 1.000 & - & 216 & 0.995 & 0.005 & 216 & 0.995 & 0.005 & - \\
\hline Chateaubriant .. & 212 & 1.000 & - & 212 & 0.991 & 0.009 & 210 & 0.952 & 0.048 & - \\
\hline \multicolumn{11}{|l|}{ Menetrol-sous- } \\
\hline Sancerre ..... & 216 & 1.000 & - & 216 & 0.949 & 0.051 & 216 & 0.958 & 0.042 & - \\
\hline Bonnac-la-Côte & 216 & 0.995 & 0.050 & 210 & 0.938 & 0.062 & 216 & 0.926 & 0.074 & - \\
\hline Chessy-les-Mines & 208 & 0.981 & 0.019 & 216 & 0.940 & 0.060 & 224 & 0.897 & 0.103 & - \\
\hline Beynost ....... & 206 & 1.000 & - & 206 & 0.888 & 0.112 & 206 & 0.913 & 0.078 & 0.009 \\
\hline Le Curtelod .... & 222 & 1.000 & - & 220 & 0.941 & 0.059 & 222 & 0.986 & 0.014 & - \\
\hline Allevard ...... & - & - & - & 236 & 0.932 & 0.068 & 240 & 0.987 & 0.013 & - \\
\hline Montauban $\ldots$ & 214 & 0.991 & 0.009 & 216 & 0.954 & 0.046 & 216 & 0.935 & 0.065 & - \\
\hline Tautavel $\ldots .$. & 216 & 1.000 & - & 214 & 0.977 & 0.023 & 216 & 0.931 & 0.069 & - \\
\hline Total or mean .. & 2922 & 0.992 & 0.008 & 3146 & 0.962 & 0.038 & 3176 & 0.955 & 0.042 & 0.003 \\
\hline$x^{2 a} \quad \ldots \ldots \ldots \ldots$ & \multicolumn{3}{|c|}{-} & \multicolumn{3}{|c|}{$80.00^{* *}(13)$} & \multicolumn{4}{|c|}{$82.75 * *(13)$} \\
\hline
\end{tabular}

$\mathbf{N}$ : number of genes sampled; $F, S$, others : alleles; populations classified according to their latitude from North to South; a) $x^{2}$ values for homogeneity between the 14 populations studied; degrees of freedom in brackets; $* *$ significant at $P<0.01$. 
using the $\chi^{2}$ analysis. Thus the comparison was carried out by the non-parametric MANN-WHITNEY $U$ test on the common allele at every locus. Table 2 gives at 5 loci (Pgm was not studied by Girard \& Palabost) the number of populations, the mean allelic frequencies, the differences between the averages and the observed $U$ values. Except for Est-C, the gene frequencies among the 5 loci studied are uniform between populations originating from the Saône and Rhône Valleys (wine-cellar populations) and populations more widely distributed throughout France (fruit populations). Fruit populations analyzed here appear to be characterized only by a higher frequency of the $F$ allele at the esterase-C locus.

\section{Correlation between gene frequencies and latitude}

Because of the overlap between the latitudinal distribution and the nature of the fruit in our populations (fig. 1), it was necessary to examine the latitudinal relationships of allelic frequencies before analyzing the role of the fruit in the differentiation of gene frequencies. Statistical analysis was carried out by SPEARMAN's rank correlation test on the common allele at each locus (table 3).

TABLE 1 (continuation)

\begin{tabular}{|c|c|c|c|c|c|c|c|c|c|c|c|}
\hline \multicolumn{4}{|c|}{ Est-6 } & \multicolumn{4}{|c|}{$\alpha-G p d h$} & \multicolumn{4}{|c|}{ Pgm } \\
\hline $\mathbf{N}$ & $F$ & $S$ & others & $\mathbf{N}$ & $F$ & $S$ & others & $\mathbf{N}$ & $F$ & $S$ & others \\
\hline 360 & 0.122 & 0.878 & - & 360 & 0.797 & 0.203 & - & - & - & - & - \\
\hline 256 & 0.316 & 0.684 & 一 & 256 & 0.492 & 0.508 & - & - & - & - & - \\
\hline 154 & 0.214 & 0.779 & 0.007 & 164 & 0.622 & 0.378 & - & 164 & 0.951 & 0.049 & - \\
\hline 216 & 0.037 & 0.963 & - & 214 & 0.430 & 0.570 & - & 216 & 0.838 & 0.162 & - \\
\hline 216 & 0.023 & 0.949 & 0.028 & 216 & 0.380 & 0.620 & - & 214 & 0.953 & 0.047 & - \\
\hline 212 & 0.415 & 0.566 & 0.019 & 210 & 0.419 & 0.581 & - & 212 & 0.882 & 0.118 & - \\
\hline 216 & 0.361 & 0.616 & 0.023 & 200 & 0.530 & 0.470 & - & 216 & 0.856 & 0.144 & - \\
\hline 210 & 0.290 & 0.667 & 0.043 & 216 & 0.648 & 0.347 & 0.005 & 216 & 0.894 & 0.106 & - \\
\hline 226 & 0.372 & 0.619 & 0.009 & 224 & 0.540 & 0.460 & - & 226 & 0.907 & 0.089 & 0.004 \\
\hline 206 & 0.369 & 0.597 & 0.034 & 206 & 0.621 & 0.379 & - & 204 & 0.848 & 0.152 & - \\
\hline 222 & 0.257 & 0.734 & 0.090 & 220 & 0.504 & 0.496 & - & 166 & 0.958 & 0.042 & - \\
\hline 238 & 0.160 & 0.840 & - & 238 & 0.714 & 0.286 & - & - & - & - & - \\
\hline 216 & 0.296 & 0.695 & 0.009 & 216 & 0.569 & 0.431 & 一 & 216 & 0.949 & 0.051 & - \\
\hline 216 & 0.157 & 0.829 & 0.014 & 216 & 0.574 & 0.426 & 一 & 216 & 0.940 & 0.060 & - \\
\hline 164 & 0.237 & 0.750 & 0.013 & 3156 & 0.570 & 0.430 & 0.0003 & 2266 & 0.905 & 0.095 & 0.0004 \\
\hline \multicolumn{4}{|c|}{$270.12 * *(13)$} & \multicolumn{4}{|c|}{$186.39 * *(13)$} & \multicolumn{4}{|c|}{$49.79 * *(10)$} \\
\hline
\end{tabular}


A correlation between $F$ allelic frequency and latitude is observed at the Adh locus $(\mathrm{r}=0.618)$. This latitudinal relationship is well known over small distances (Grossman et al., 1970 ; PiPKIN et al., 1973) as over larger ones (ANDERSON, 1981 ; JOHNSON \& SCHAFFER, 1973 ; OAKESHOTT et al., 1982). The 5 other coefficients are not statistically significant. This means that for these loci (Acph, Est-6, Est-C, $\alpha-G p d h$ and $P g m$ ) a comparison between the populations, grouped according to the kind of fruit in the collecting localities, is available.

TABLE 2

Allele frequencies at five polymorphic loci in populations studied by us and in studies by GiRARD \& PALABOST (1976).

Comparaison entre nos résultats et ceux précédemment publiés par GiRaRd \& Palabost (1976).

\begin{tabular}{|c|c|c|c|c|c|}
\hline \multirow{2}{*}{ Locus } & \multirow{2}{*}{$\begin{array}{c}\text { Alleles } \\
\text { or number } \\
\text { of populations }\end{array}$} & \multirow{2}{*}{$\begin{array}{c}\text { Populations } \\
\text { of the Saône } \\
\text { and Rhône valleys } \\
\text { (wine-cellar } \\
\text { populations, } \\
\text { from GiRARD } \\
\text { and PALABOst, 1976) }\end{array}$} & \multirow{2}{*}{$\begin{array}{c}\text { Populations originating } \\
\text { from different regions } \\
\text { of France } \\
\text { (fruit populations ; } \\
\text { present study) }\end{array}$} & \multicolumn{2}{|c|}{ Comparison } \\
\hline & & & & $d$ & $\mathbf{U}$ \\
\hline$A c p h$ & $\begin{array}{l}\mathrm{n} \\
F \\
F \\
S\end{array} \ldots \ldots \ldots \ldots \ldots$ & $\begin{array}{c}15 \\
0.991 \pm 0.002 \\
0.009 \pm 0.002\end{array}$ & $\begin{array}{c}13 \\
0.992 \pm 0.003 \\
0.008 \pm 0.003\end{array}$ & 0.001 & 77 \\
\hline$A d h$ & 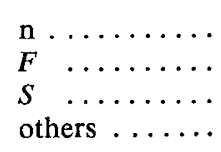 & $\begin{array}{c}15 \\
0.959 \pm 0.005 \\
0.040 \pm 0.005 \\
0.001 \pm 0.001\end{array}$ & $\begin{array}{c}14 \\
0.962 \pm 0.007 \\
0.038 \pm 0.007 \\
-\end{array}$ & $\begin{array}{l}0.003 \\
0.002 \\
0.001\end{array}$ & 99 \\
\hline Est-C & 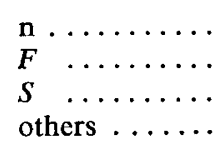 & $\begin{array}{c}15 \\
0.883 \pm 0.009 \\
0.087 \pm 0.008 \\
0.030 \pm 0.005\end{array}$ & $\begin{array}{c}14 \\
0.955 \pm 0.007 \\
0.042 \pm 0.007 \\
0.003 \pm 0.002\end{array}$ & $\begin{array}{l}0.072 \\
0.045 \\
0.027\end{array}$ & $23^{* * *}$ \\
\hline Est-6 & $\begin{array}{l}\mathrm{n} \ldots \ldots \ldots \\
F \\
S^{\prime} \ldots \ldots \cdots \\
\text { others } \ldots \ldots\end{array}$ & $\begin{array}{c}15 \\
0.272 \pm 0.012 \\
0.712 \pm 0.012 \\
0.016 \pm 0.003\end{array}$ & $\begin{array}{c}14 \\
0.237 \pm 0.015 \\
0.750 \pm 0.015 \\
0.013 \pm 0.004\end{array}$ & $\begin{array}{l}0.035 \\
0.038 \\
0.003\end{array}$ & 93.5 \\
\hline$\alpha-G p d h$ & 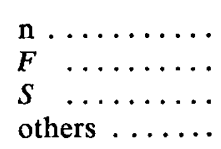 & $\begin{array}{c}15 \\
0.529 \pm 0.014 \\
0.468 \pm 0.014 \\
0.003 \pm 0.001\end{array}$ & $\begin{array}{c}14 \\
0.570 \pm 0.017 \\
0.430 \pm 0.017 \\
-\end{array}$ & $\begin{array}{l}0.041 \\
0.038 \\
0.003\end{array}$ & 87 \\
\hline
\end{tabular}

$\mathrm{n}$ : number of populations; $F, S$, others : alleles; $\mathrm{d}:$ differences; $\mathrm{U}:$ Mann and Whitney's variable; ${ }^{* *}$ significant at $\mathrm{P}<0.01$. 
TABLE 3

SPEARMAN's rank correlation coefficients ( $r$ ) of AcphF, AdhF, Est-CF,

Est-6S, $\alpha-G p d h^{F}, P g m^{F}$ frequencies with latitude.

Coefficients de corrélation de SPEARMan ( $r$ )

entre les fréquences des allèles communs et la latitude.

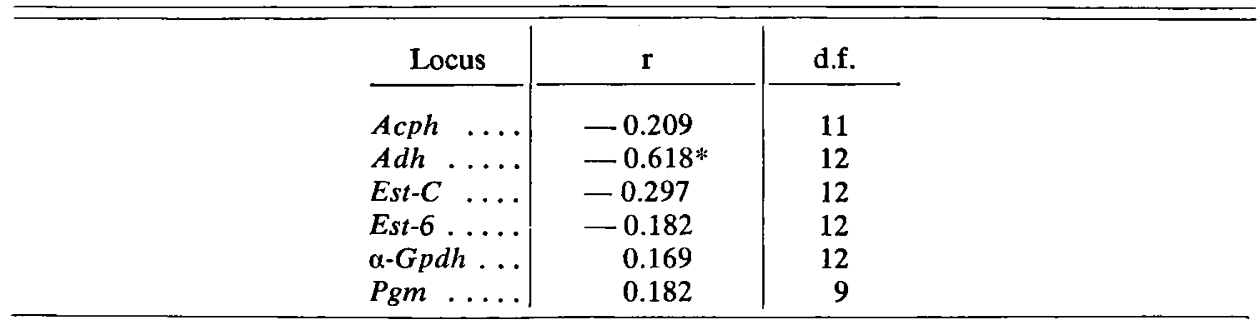

d.f. : degree of freedom; $*$ significant at $\mathbf{P}<0.05$.

TABLE 4

Allele frequencies in populations classified by type of fruit.

Comparaison entre les populations classées selon la nature du fruit de piégeage.

\begin{tabular}{|c|c|c|c|c|c|}
\hline Locus & $\begin{array}{c}\text { Alleles } \\
\text { or number } \\
\text { of } \\
\text { populations }\end{array}$ & Apple & Plum & Other Fruit & $\mathbf{H}$ \\
\hline$A c p h$ & $\mid \begin{array}{lll}n & \ldots & \ldots \\
\boldsymbol{F} & \ldots & \ldots \\
\boldsymbol{S} & \ldots \ldots & \ldots\end{array}$ & $\begin{array}{c}5 \\
0.988 \pm 0.006 \\
0.012 \pm 0.006\end{array}$ & $\begin{array}{c}4 \\
0.995 \pm 0.005 \\
0.005 \pm 0.005\end{array}$ & $\begin{array}{c}4 \\
0.997 \pm 0.003 \\
0.003 \pm 0.003\end{array}$ & 0.36 \\
\hline$A d h$ & 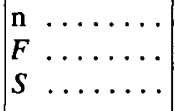 & $\begin{array}{c}5 \\
0.988 \pm 0.006 \\
0.012 \pm 0.006\end{array}$ & $\begin{array}{c}4 \\
0.942 \pm 0.016 \\
0.058 \pm 0.016\end{array}$ & $\begin{array}{c}5 \\
0.948 \pm 0.013 \\
0.052 \pm 0.013\end{array}$ & $6.12 *$ \\
\hline Est-C & 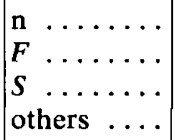 & $\begin{array}{c}5 \\
0.974 \pm 0.009 \\
0.020 \pm 0.008 \\
0.006 \pm 0.004\end{array}$ & $\begin{array}{c}4 \\
0.930 \pm 0.017 \\
0.068 \pm 0.017 \\
0.002 \pm 0.002\end{array}$ & $\begin{array}{c}5 \\
0.954 \pm 0.012 \\
0.046 \pm 0.012 \\
-\end{array}$ & 3.54 \\
\hline Est-6 & 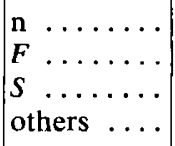 & $\begin{array}{c}5 \\
0.142 \pm 0.020 \\
0.852 \pm 0.020 \\
0.006 \pm 0.004\end{array}$ & $\begin{array}{c}4 \\
0.379 \pm 0.032 \\
0.600 \pm 0.033 \\
0.021 \pm 0.010\end{array}$ & $\begin{array}{c}5 \\
0.230 \pm 0.025 \\
0.755 \pm 0.025 \\
0.015 \pm 0.007\end{array}$ & $10.99 * *$ \\
\hline$\alpha-G p d h$ & 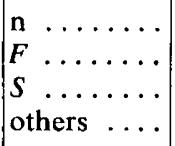 & $\begin{array}{c}5 \\
0.569 \pm 0.028 \\
0.431 \pm 0.028 \\
-\end{array}$ & $\begin{array}{c}4 \\
0.527 \pm 0.034 \\
0.473 \pm 0.034 \\
-\end{array}$ & $\begin{array}{c}5 \\
0.604 \pm 0.029 \\
0.395 \pm 0.029 \\
0.001 \pm 0.001\end{array}$ & 1.62 \\
\hline$P g m$ & $\mid \begin{array}{lll}\mathbf{n} & \ldots & \ldots \\
\boldsymbol{F} & \ldots & \ldots \\
S & \ldots & \ldots \\
\text { others } & \ldots\end{array}$ & $\begin{array}{c}3 \\
0.911 \pm 0.023 \\
0.089 \pm 0.023 \\
-\end{array}$ & $\begin{array}{c}4 \\
0.874 \pm 0.022 \\
0.125 \pm 0.022 \\
0.001 \pm 0.001\end{array}$ & $\begin{array}{c}4 \\
0.934 \pm 0.017 \\
0.066 \pm 0.017 \\
-\end{array}$ & 3.08 \\
\hline
\end{tabular}

n : number of populations ; $F, S$, others : alleles; $H:$ Kruskal and Wallis's variable ; * : significant at $\mathbf{P}<0.05 ; * *$ : significant at $\mathbf{P}<0.01$. 


\section{Influence of the type of fruit in the population studied}

The heterogeneity demonstrated in table 1 might be due to the kind of fruit on which the populations had been collected. So we have divided the populations into 3 groups : apples, plums and other fruit (varied fruits such as tomatoes, melons, peaches). Comparison between the populations of the 3 groups was carried out by the KRUSKAL-WALLIS $\mathrm{H}$ test on the common alleles (tables have been used for small samples : see BEYER, 1981). Table 4 gives the number of populations, the mean allelic frequencies in the 3 groups and the $H$ values obtained after comparison between these groups. A survey of this table shows significant differences between the 3 groups in the cases of $A d h$ and Est-6 loci. Since for $A d h$ a correlation with latitude was mentioned above (table 3) and since latitudinal and fruit distributions of the populations studied here are overlapping, the influence of fruit on the gene frequencies can be taken into account only for the case of Est-6. The Est-6s allele has the highest frequency $(0.852 \pm 0.020)$ in apple populations, the smallest in plum populations $(0.600 \pm 0.033)$ and an intermediate value $(0.755 \pm 0.025)$ in the other fruit populations.

\section{Discussion and conclusion}

The results presented here provide a larger description of the biochemical polymorphism in French populations of Drosophila melanogaster.

The 14 new populations originating from different geographical areas (fig. 1) show a more or less high level of variability at the 6 loci studied (table 1). Curiously, in spite of this heterogeneity, the patterns of the allelic frequency distribution are similar between these 14 populations and those previously described by GIRARD \& Palabost in 1976 (table 2). Because all of Girard \& Palabost's populations were sampled from the same geographical area, we can note that the extension of the geographical origin of the populations analyzed has not provided a differentiation in the allelic frequency distribution for four enzymatic loci out of the five compared. Moreover, as these new populations have been captured from fruit, it appears that habitats different from wine-cellars have not induced particular patterns of allelic frequencies. Thus, despite the small number of loci studied, it seems that temperate habitats in France do not vary enough to provide much genetic differentiation in the case of enzymatic polymorphism. DAvid (1982) has also analyzed 5 other French populations sampled in different habitats (wine-cellars, fruit or urban habitats); 4 of them were located in the same geographical area as those of Girard \& Palabost, the 5 th coming from Corsica. At the 4 loci commonly examined by David and us (presently and in the note of 1976) the allelic frequencies are similar. DAvid's data showed that $F$ allele of the Adh locus was favored in wine-cellar populations. With our 14 new populations, no significant difference between wine-cellar and fruit populations is observed at $A d h$.

Nevertheless, in regard to the role of the nutritive resources some observations are noteworthy for the fruit populations. The 3 kinds of fruit (apples, plums and others) have induced a genetic differentiation at the $A d h$ and Est-6 loci (table 4), but the result is uncertain for $A d h$ because a latitudinal cline is also observed (table 3 ). 
In the case of Est-6 it should be noted that the $S$ allele is at the highest frequency in apple populations $(0.852 \pm 0.020)$ and at the lowest in plum populations $(0.600 \pm 0.033)$. As can be seen in figure 1, apple populations are all located in the same region of France (North-West) and plum populations in different regions : North-West (population 6), Center (population 7), and South-East (populations 9 and 10). Thus, because the resources have a geographical pattern, further studies are necessary before we can conclude unambiguously as to their role in the differentiation of allelic frequencies at the Est-6 locus. Whatever the case, this result can argue in favor of the influence of selection on the Est-6 locus, as has been demonstrated in the laboratory (DANFORD \& BEARDMORE, 1980) and in natural (OAKESHOTT et al., 1981) populations.

Up to now, despite some particular local situations, the different studies of French natural populations show that the distributions of the allelic frequencies at most loci are very similar, independently of geographical situation and habitats. However, they differ from populations originating in other continents (OAKESHOTT et al., 1981, 1982, 1983). Different hypotheses can be suggested to explain this result relative to the French populations. First, if migrations are important between the numerous wine-cellar populations (wine-cellars are certainly the most common habitat of Drosophila melanogaster in France) and those living in other habitats (such as orchards and kitchen-gardens), this could explain the similarity in the distributions of allozyme frequencies. Secondly, the selective pressures in the different microhabitats of Drosophila melanogaster in temperate countries like France would not be sufficient to allow a great between-populations differentiation at the enzymatic polymorphism level.

\section{Acknowledgements}

We are very grateful to Professor C. Petit for helpful comments. We thank Professor D. ANXolabehere who made useful suggestions. We thank M. BouletreaU, A. Fleuriet and S. RONSSERAY for collecting the populations. programs.

This study was carried out as part of the C.N.R.S.'s ERA 406 and GRECO 44 research

Received July 10, 1984.

Accepted December 12, 1984.

\section{References}

ANDERSON P.R., 1981. Geographic clines and climatic associations of $A d h$ and $\alpha-G p d h$ gene frequencies in Drosophila melanogaster. In : GiBSON J.B., OAKESHOTT J.G. (ed.), Genetic studies of Drosophila populations, 237-250. Australian National University.

Ayala F.J., Powell J.R., Tracey M.L., Mourao C.A., Perez-Salas S., 1972. Enzyme variability in the Drosophila willistoni group. IV. Genic variation in natural populations of Drosophila willistoni. Genetics, 70, 113-139.

BERGER M., 1971. A temporal survey of allelic variation in natural and laboratory populations of Drosophila melanogaster. Genetics, 67, 121-136. 
BEYER W.H., 1981. Handbook of tables for probability and statistics, 2nd edition. Ed. C.R.C. press, Inc. Boca Raton, Florida, U.S.A.

Danford N.D., BEARDMORE J.A., 1980. Selection at the esterase-6 locus in Drosophila melanogaster by added enzyme substrates in the culture medium. Genetica, 51, 171-178.

David J., 1982. Latitudinal variability of Drosophila melanogaster : allozyme frequencies divergence between european and afrotropical populations. Biochem. Genet., 20, 747-761.

Girard P., Palabost L., 1976. Etude du polymorphisme enzymatique de 15 populations naturelles de Drosophila melanogaster. Arch. Zool. Exp. Gén., 117, 41-55.

Girard P., Palabost L., Petit C., 1977. Enzymatic variation at seven loci in nine natural populations of Drosophila melanogaster. Biochem. Genet., 15, 589-599.

Grossman A.I., Koreneva L.G., Witskaya L.E., 1970. Variability of alcohol dehydrogenase (Adh) locus in natural populations of Drosophila melanogaster. Genetika S.S.R., 6 , 91-96.

Johnson F.M., Schaffer H.E., 1973. Isozyme variability in species of the genus Drosophila. VII. Genotype environment relationships in populations of Drosophila melanogaster from the eastern United States. Biochem. Genet., 10, 149-163.

OAKeshott J.G., Chambers G.K., Gibson J.B., Willcocks D.A., 1981. Latitudinal relationships of esterase- 6 and phosphoglucomutase gene frequencies in Drosophila melanogaster. Heredity, 47, 385-396.

Oakeshott J.G., Gibson J.B., Anderson P.R., Knibb W.R., Anderson D.G., Chambers G.K., 1982. Alcohol dehydrogenase and glycerol-3-phosphate dehydrogenase clines in Drosophila melanogaster on different continents. Evolution, 36, 86-96.

OAKeshott J.G., Gibson J.B., Willcocks D.A., Chambers G.K., 1983. Latitudinal variation in octanol dehydrogenase and acid phosphatase allele frequencies in Drosophila melanogaster. Theor. Appl. Genet., 65, 191-196.

O'BRIEN S.J., MacinTYRE R.J., 1969. An analysis of gene-enzyme variability in natural populations of Drosophila melanogaster and Drosophila simulans. Am. Nat., 103, 97-113.

Pipkin S.B., Rhodes C., Williams N., 1973. Influence of temperature on Drosophila alcohol dehydrogenase polymorphism. J. Hered., 64, 181-185.

Poulik M.D., 1957. Starch gel electrophoresis in a discontinuous system of buffer. Nature, $180,1477-1479$.

Singh R.S., Hickey D.R., David J., 1982. Genetic differentiation between geographically distant populations of Drosophila melanogaster. Genetics, 101, 235-256. 